\title{
KOROSIFITAS PADA TANAH LAPUKAN VULKANIK BERDASARKAN NILAI TAHANAN JENIS TANAH DI KAWASAN UNPAD JATINANGOR, KABUPATEN SUMEDANG, JAWA BARAT
}

\author{
Yanwar Yusup Rukmana ${ }^{1}$, Zufialdi Zakaria ${ }^{1}$, Dicky Muslim ${ }^{1}$, dan Nadhirah Seraphine ${ }^{2}$, \\ ${ }^{1}$ Fakultas Teknik Geologi, Universitas Padjadjaran, ${ }^{2}$ Uppsala University, Swedia \\ e-mail : yanwaryr@gmail.com
}

\begin{abstract}
Abstrak. Pembangunan infrastruktur terutama gedung-gedung tinggi tidak terlepas dari penggunaan material logam. Masalah besar bagi bangunan dan peralatan yang menggunakan material logam adalah korosi. Parameter yang berpengaruh dalam menentukan korosifitas pada tanah yaitu karakteristik tanah dan nilai tahanan jenis tanah. Nilai tahanan jenis tanah berperan sangat signifikan karena korosifitas merupakan fungsi dari konduktivitas listrik. Pengambilan sampel tanah dilakukan secara tak tergangu (UDS). Sampel tanah sebanyak 33 tabung diambil dari 11 titik pengamatan pada setiap kedalaman 0,5m, 1,0m dan 1,5m. Pengukuran nilai tahanan jenis tanah pada penelitian ini mengacu pada ASTM G187-12. Karakteristik tanah pada lapukan vulkanik didominasi oleh tanah dengan besar butir halus yaitu Lanau hingga Lempung. Berdasarkan hasil pengamatan di lapangan dan pengujian di laboratorium, tanah di kawasan Unpad Jatinangor, Kabupaten Sumedang, Jawa Barat berjenis tanah Lanau dengan tingkat plastisitas rendah-tinggi ( $\mathrm{MH}-\mathrm{ML}$ ) serta Lempung dengan tingkat plastisitas tinggi $(\mathrm{CH})$. Hasil analisis dari sebaran potensi korosifitas tanah berdasarkan ASTM,2012 di dalam Pritchard dkk., 2013 menunjukkan bahwa tingkat korosifitas tanah berada pada tingkatan sedang-tinggi. Zona korosifitas tinggi pada sampel dengan kedalaman 0,5 m terkonsentrasi di barat laut daerah penelitian, pada sampel dengan kedalaman $1,0 \mathrm{~m}$ terkonsentrasi di tenggara daerah penelitian, dan pada sampel dengan kedalaman $1,5 \mathrm{~m}$ tersebar di seluruh kawasan Universitas Padjadjaran Jatinangor.
\end{abstract}

Kata Kunci: Korosifitas; Vulkanik; Tahanan Jenis; Tanah

\begin{abstract}
Infrastructure development, especially tall buildings, is inseparable from the use of steel or iron materials. The big problem for buildings and equipment that used metal materials is corrosion. Corrosion is degradation of metal quality because chemical reaction with its environment, including soil. The main indicator that is very significant in determining corrosion in soils is the value of resistivity. It is because the rate of corrosivity is a function of the electrical conductivity and characteristics of the soil itself. The soil resistivity in this study refers to ASTM G187-12. The characteristics of volcanic weathered soil are dominated by a lot of fine grains. Based on observations in the field and testing in the laboratory, soils in the study area type is Silt with Low-High Plasticity (MH-ML) and Clay with High Plasticity (CH). The results of the distribution analysis of soil corrosivity in the study area at Medium-High level based on ASTM, 2012 Pritchard et.al., 2013. The high zone of corrosivity in samples with a depth of $0.5 \mathrm{~m}$ is concentrated in the northwest, in samples with a depth of $1.0 \mathrm{~m}$ concentrated in the southeast, and in samples with a depth of $1.5 \mathrm{~m}$ scattered throughout the area of Padjadjaran University Jatinangor.
\end{abstract}

Keywords: Corrosivity; Volcanic; Resistivity; Soil

\section{PENDAHULUAN}

Pembangunan infrastruktur terutama gedunggedung tinggi tidak terlepas dari penggunaan material logam. Selain itu, hampir semua peralatan yang dipergunakan manusia terbuat dari logam (Lestari, 2019). Masalah besar bagi bangunan dan peralatan yang menggunakan material logam adalah korosi (Reiger, 1992). Korosi merupakan penurunan mutu logam akibat reaksi kimia suatu logam dengan lingkungannya ((Bradford, 2001), (Bahri, 2007), dan (Sidiq, 2013)). Lingkungan yang dimaksud bisa berupa udara (dengan sinar matahari), embun, air (tawar, laut, sungai, hujan, danau dan rawa) juga tanah (Wahyuni dan Ab, 2014). Tanah berperan sebagai elektrolit yang memiliki banyak variabelvariabel seperti: kandungan air, $\mathrm{pH}$, jenis mineral, nilai tahanan jenis tanah dan parameter kimia-fisika lainnya (Warnana dkk., 2015) dan (Putra, 2018).

Daerah penelitian berada di kawasan kampus Universitas Padjadjaran Jatinangor. Daerah kawasan pendidikan dengan beberapa Universitas dan apartemen-apartemen yang sudah mulai dibangun 
(Muslim dkk., 2015). Secara geologi kawasan Unpad Jatinangor merupakan daerah vulkanik. Lapukan endapan vulkanik menghasilkan tanah dengan butiran halus (N. Khoirullah, 2016). Tanah dengan ukuran butir halus memiliki kemampuan menyerap volume air dalam jumlah yang lebih besar dibanding dengan jenis tanah lainnya. Dengan kata lain semakin tinggi persentase butiran halus pada tanah, semakin tinggi kadar air (Farahnaz dkk., 2018).

Semakin tinggi kandungan air dalam tanah maka sifat konduktifitas tanah akan semakin tinggi dan nilai tahanan jenisnya akan semakin rendah (Irianto dan Rahmawati, 2014). Nilai tahanan jenis tanah merupakan indikator utama yang sangat signifikan dalam menentukan tingkat korosi karena laju dari korosifitas merupakan fungsi dari konduktivitas listrik (Okiongbo dan Ogobiri, 2013).

Pada artikel ini akan dipaparkan mengenai beberapa parameter keteknikan pada tanah serta mencari tahu bagaimana hubungan antar parameter-parameter tersebut sehingga berpengaruh secara signifikan terhadap klasifikasi korosifitas tanah.

\section{GEOLOGI REGIONAL DAERAH PENELITIAN}

Berdasarkan peta geologi regional (Silitonga, 2003) pada gambar 1 kawasan kampus Unpad Jatinangor tersusun atas material gunung api muda tak teruraikan (Qyu) yang berumur kuarter. Satuan material gunung api muda tak teruraikan (Qyu) memiliki litologi berupa Pasir Tufaan, Lapili, breksi, lava, dan aglomerat. Sebagian berasal dari Gunung Tangkuban Parahu dan sebagian dari Gunung Tampomas. Batuan dari Gunung Tangkuban Parahu maupun Tampomas diklasifikasikan kedalam jenis batuan menengah (andesit basaltik) dengan kandungan $\mathrm{SiO} 2$ antara 52,99\%-53,25\% (Hutabarat dkk., 2016).

Hasil dari pelapukan litologi-litologi tersebut kemudian membentuk tanah dengan butiran halus yang cukup tinggi. Menurut (Arifin dkk., 2018) di dalam penelitiannya menyebutkan, rata-rata nilai $\mathrm{pH}$ tanah permukaan di Jatinangor berkisar antara 6,19 - 6,49 artinya dapat dikatakan mendekati netral. Besar-kecilnya nilai $\mathrm{pH}$ dipengaruhi oleh seberapa banyak kandungan C-Organik (Thomas dan Hargrove, 1984), karakteristik tanah dan Air, pengendapan material, vegetasi dan kedalaman tanah (Hanafiah, 2007).

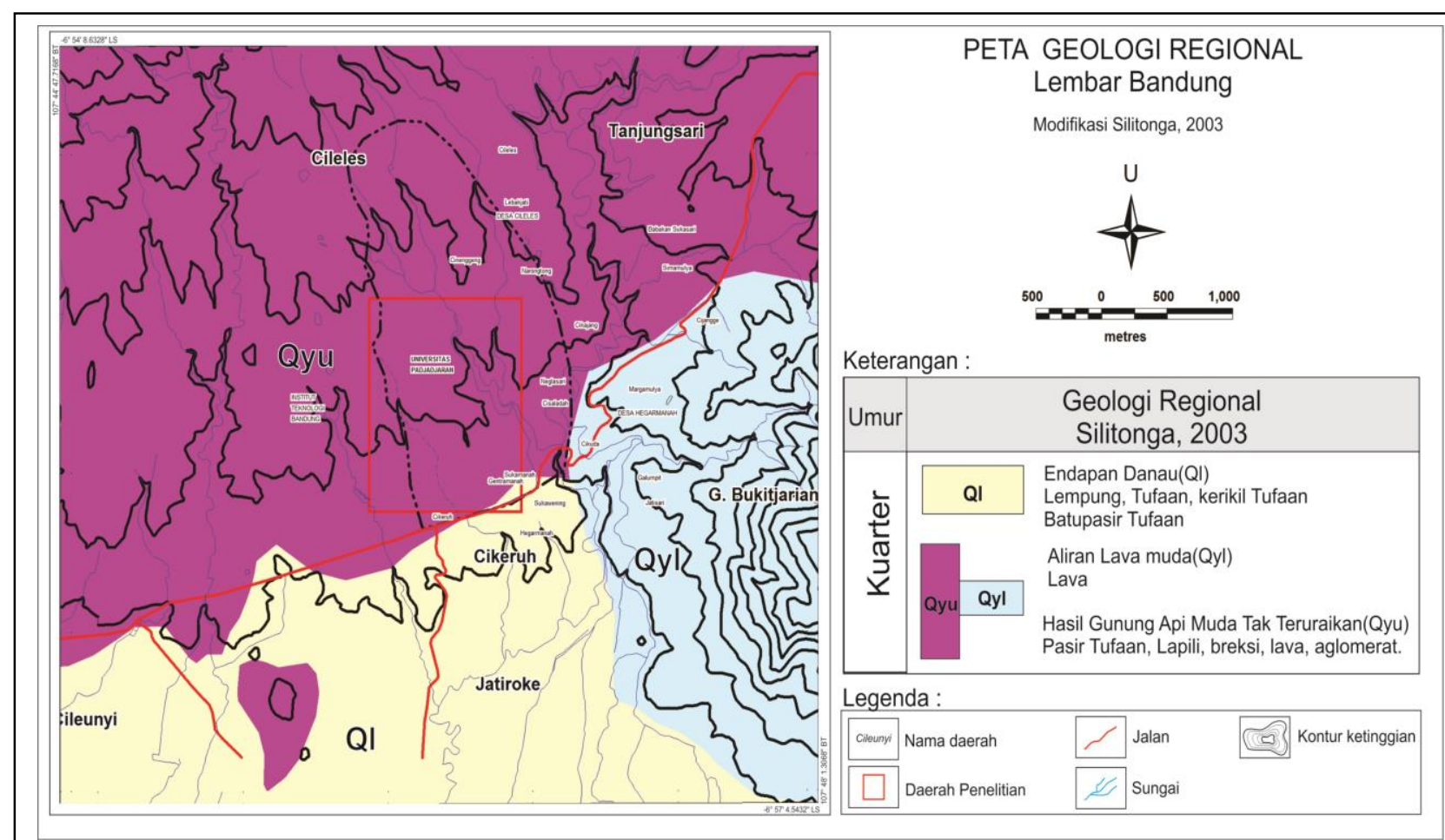

Gambar 1. Geologi Daerah Penelitian, modifikasi dari Silitonga (2003) 


\section{Pengukuran}

Konsep dasar pengukuran nilai tahanan jenis yang digunakan mengacu pada ASTM G187-12. Skema pengukuran tahanan jenis tanah dengan metode soil box (gambar 2) yakni: Arus listrik DC (i) dialirkan kedalam sampel yang berada pada soil box yang memiliki panjang (L) dan luas permukaan (A) sehingga terjadi beda potensial (v). Kemudian untuk mendapatkan nilai tahanan jenis tanah parameterparameter tadi dimasukkan kedalam persamaan di bawah sehingga didapatkan nilai tahanan jenis tanah dari setiap sampel.

$$
R=\rho \frac{L}{A}
$$

$$
\text { Dengan: }
$$

$\mathrm{R}$

:Tahanan Jenis Listrik $(\Omega)$

$\rho \quad$ :Tahanan Jenis Tanah $(\Omega \mathrm{m})$

L $\quad$ :Jarak Dua Elektroda $(\mathrm{cm})$

A :Luas Permukaan Sampel yang Dialiri Listrik $\left(\mathrm{cm}^{2}\right)$

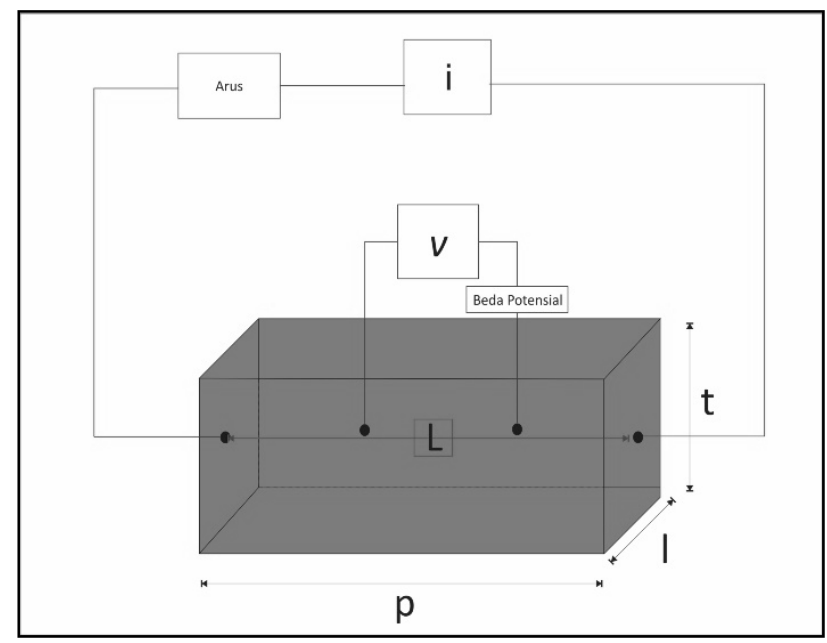

Gambar 2. Skema Pengukuran Tahanan Jenis Tanah Dengan Soil box

Nilai tahanan jenis tanah dijadikan sebagai indikator untuk menentukan klasifikasi nilai korosi tanah. Ketika nilai tahanan jenis tanah rendah (konduktivitas tinggi) menghasilkan tingkat korosifitas yang tinggi. Sebaliknya, ketika nilai tahanan jenis tanah tinggi (konduktivitas rendah) menghasilkan tingkat korosifitas yang rendah (Warnana dkk., 2015). Perbedaan nilai tahanan jenis pada tanah disebabkan dari derajat pelapukan batuan asalnya (Reynolds, 2011). Pada tabel 1 terlihat rentang nilai tahanan jenis tanah dari beberapa material.

Tabel 1. Nilai Tahanan Jenis Beberapa Material Geologi (U. S. Army Corps of Engineers, 1997) di dalam (Okiongbo dan Ogobiri, 2013).

\begin{tabular}{c|c}
\hline Jenis Tanah/material & $\begin{array}{c}\text { Tahanan jenis } \\
(\boldsymbol{\Omega m})\end{array}$ \\
\hline Clay & $1-100$ \\
Silts & $10-150$ \\
Alluvium & $10-800$ \\
Sandstone & $8-4000$ \\
Shale & $20-2000$ \\
Granite & $5000-5 \times 10^{6}$ \\
Basalt & $1000-10^{6}$ \\
Groundwater (fresh) & $10-100$ \\
Sea water & 0.2 \\
\hline
\end{tabular}

\section{Korosifitas Tanah}

(Sidiq, 2013) menjelaskan bahwa proses korosi secara elektro-kimia pada tanah (gambar 3) terdiri dari 4 komponen utama yaitu: Anoda (Kutub negatif), Katoda (kutub positif), Elektrolit, dan terhubungnya anoda - katoda.

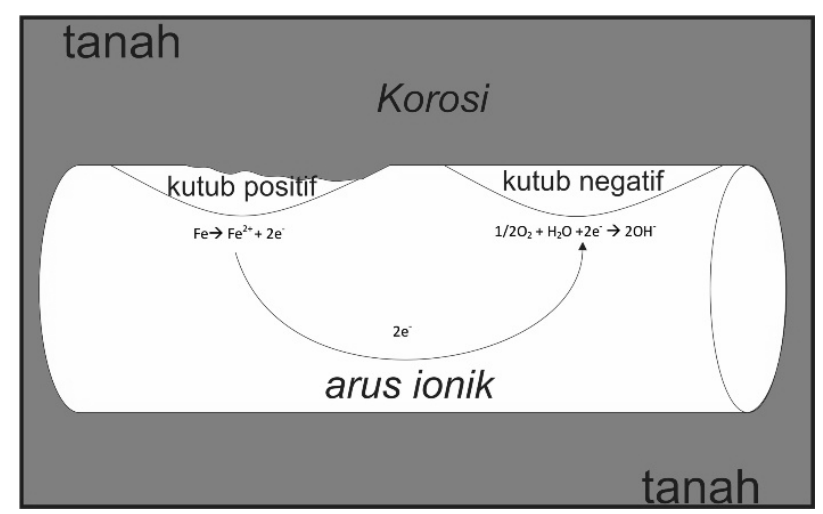

Gambar 3. Proses Korosi Pada Pipa Besi (modifikasi dari (G Camitz, 1994))

Peranan dari komponen-komponen diatas secara langsung terdapat pada parameter-parameter karakteristik keteknikan tanah. Beberapa parameter tersebut adalah: (1) air berperan sebagai cairan elektrolit; (2) derajat aerasi berperan dalam reaksi katodik; (3) $\mathrm{pH}$ berperan sebagai solubilitas produk korosi dan juga aktivitas alami mikrobiologi; (4) 
tahanan jenis tanah sebagai ionic current ketika terjadi reaksi oksidasi. Tanah dengan tahanan jenis tinggi akan memperlambat reaksi korosi. Secara umum ketika tahanan jenis tanah turun maka kandungan air naik; (5) kandungan geokimia tanah seperti sulfat dan klorida (Anon, 2012).

Klasifikasi korosifitas tanah dengan indikator nilai tahanan jenis tanah mengacu berdasarkan tabel $2 \mathrm{di}$ bawah ini.

Tabel 2. Nilai Tahanan Jenis dan Klasifikasi Korositas ( (ASTM G187-12, 2012) di dalam (Pritchard dan Hallett, 2013))

\begin{tabular}{c|c}
\hline Tahanan Jenis $(\Omega m)$ & Klasifikasi Korosifitas \\
\hline$<10$ & Sangat Tinggi \\
$10,01-20,00$ & Tinggi \\
$20,01-50,00$ & Sedang \\
$50,01-100,00$ & Rendah \\
$>100,00$ & Sangat Rendah \\
\hline
\end{tabular}

\section{METODOLOGI}

Secara garis besar penelitian ini dilakukan dalam beberapa tahapan, yaitu:

1. Pekerjaan lapangan : memetakan sebaran jenis tanah permukaan dan pengambilan sampel tanah tak terganggu. Sampel tanah yang diambil berasal dari 11 titik pengamatan yang tersebar di daerah penelitian dengan variasi kedalaman yang diambil berdasarkan pembagian lapisan tanah dangkal secara umum yaitu pada kedalaman $0,5 \mathrm{~m}, 1,0 \mathrm{~m}$ dan 1,5 m (gambar 4).

2. Pekerjaan laboratorium : pengujian sampel tanah di laboratorium bertujuan untuk mengetahui karakteristik keteknikan tanah. Beberapa pengujian tersebut adalah: kadar air (ASTM D2216), batas atterberg (ASTM D4318), persentase besar butir tanah (ASTM D7928, D6913), dan nilai tahanan jenis tanah (ASTM G187-12).

3. Pengolahan data dan analisis : berdasarkan hasil pengamatan dilapangan dan data hasil pengujian di laboratorium selanjutnya dilakukan analisis korelasi terhadap parameter-parameter yang berpengaruh terhadap korosifitas baik itu secara langsung maupun tidak langsung. Selanjutnya dibuat pula peta sebaran potensi korosifitas tanah di daerah penelitian.

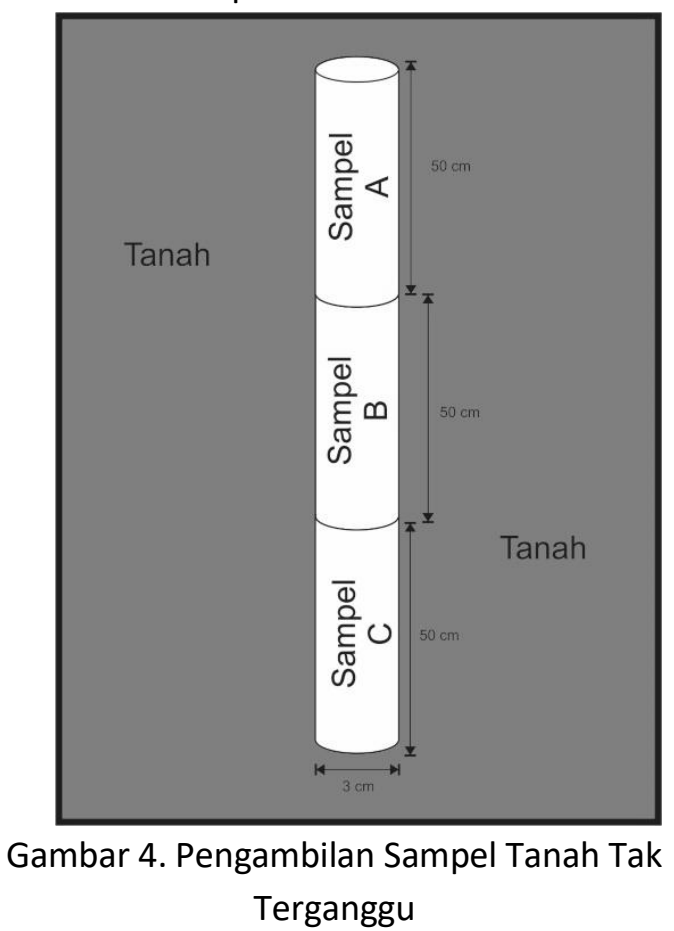

\section{HASIL PENELITIAN}

Litologi daerah penelitian didominasi oleh material vulkanik seperti breksi dan tuff. Litologi tersebut terlapukan hingga membentuk tanah dengan butiran halus. Hasil ini dapat terlihat dari pengujian analisis besar butir yang dilakukan terhadap 33 sampel yang diambil. Pada sampel yang diambil di kedalaman 0,5 m persentase butiran kasar berkisar antara 2,52\% - 16,28\%. Sedangkan butiran halus berkisar antara $83,72 \%-100 \%$. Pada sampel yang diambil di kedalaman $1,0 \mathrm{~m}$ persentase butiran kasar berkisar antara 2,68\% - 15.70\%. Sedangkan butiran halus berkisar antara $84,30 \%-100 \%$. Pada sampel yang diambil di kedalaman 1,5 m persentase butiran kasar berkisar antara 2,50\% - 19.90\%. Sedangkan butiran halus berkisar antara $80,10 \%$ $100 \%$.

Berdasarkan pemetaan geoteknik, analisis besar butir/uji ayak dan pengujian batas atterberg yang telah dilakukan, sebaran tanah di daerah penelitian berjenis Lanau dengan tingkat plastisitas rendahtinggi (MH-ML) serta Lempung dengan tingkat Plastisitas Tinggi $(\mathrm{CH})$ (gambar 5). Nilai persentase Lanau pada tanah berjenis MH-ML berkisar antara 
43,69\% - 51,29\% dan Indeks plastisitasnya berkisar antara $13,58 \%-46,02 \%$.

Sedangkan nilai persentase Lempung pada tanah berjenis $\mathrm{CH}$ berkisar antara $42,03 \%-88,43 \%$ dan Indeks plastisitasnya berkisar antara 22,26\%-54,90\%.

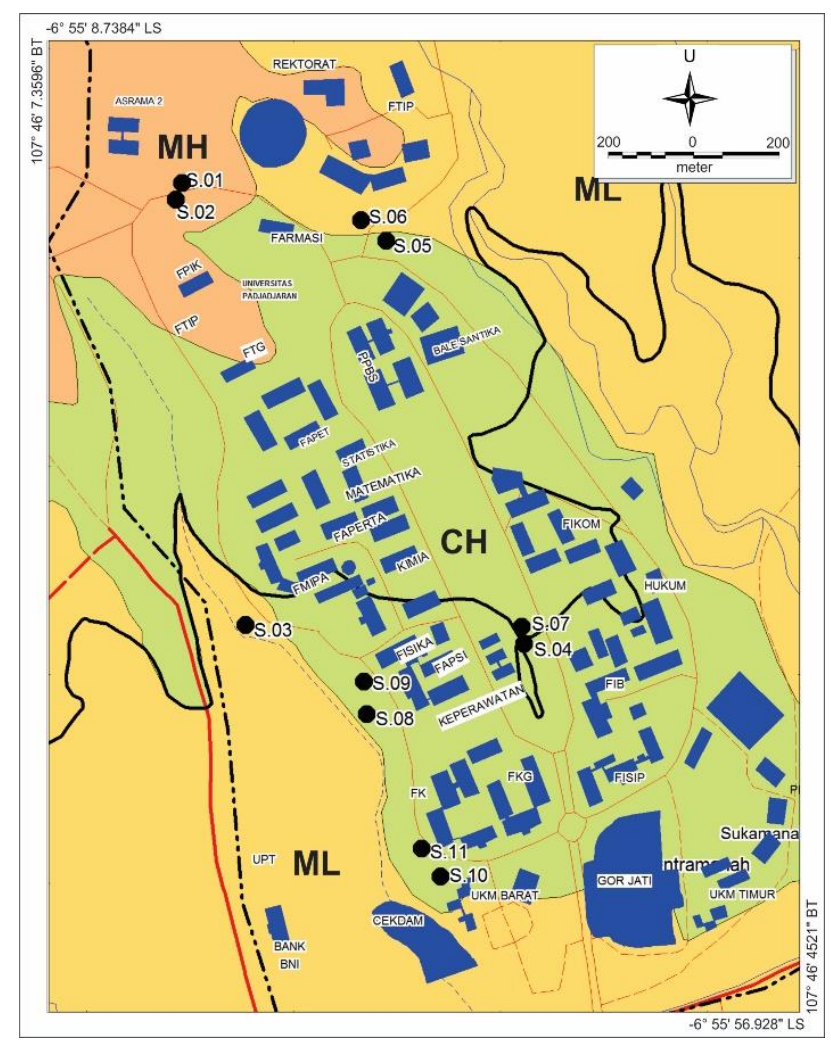

Gambar 5. Peta Sebaran Jenis Tanah di daerah Penelitian

Hasil pengukuran nilai tahanan jenis tanah pada variasi kedalaman $0,5 \mathrm{~m} ; 1,0 \mathrm{~m}$; dan $1,5 \mathrm{~m}$ (gambar 6) terlihat bahwa semakin bertambahnya kedalaman, semakin rendah nilai tahanan jenisnya.

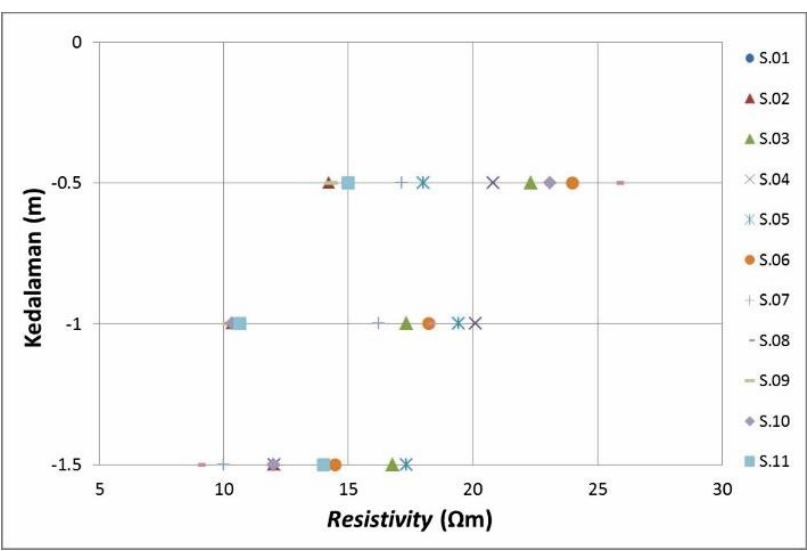

Gambar 6. Sebaran Nilai Tahanan Jenis Pada Setiap Kedalaman Pengambilan Sampel
Parameter lain yang terlihat dari hasil pengujian di laboratorium dan sangat berpengaruh terhadap potensi korosifitas tanah adalah kadar air. Pada sampel yang diambil di kedalaman $0,5 \mathrm{~m}$ persentase kadar air berkisar antara 33,96\% - 68,93\%. Pada sampel yang diambil di kedalaman $1,0 \mathrm{~m}$ persentase kadar air berkisar antara 26,81\% - 76,14\%. Sedangkan pada sampel yang diambil di kedalaman $1,5 \mathrm{~m}$ persentase kadar air berkisar antara $30,31 \%$ $55,97 \%$.

Selanjutnya, dari nilai tahanan jenis tanah di daerah penelitian tersebut kemudian dilakukan interpolasi menggunakan metode Kriging dengan bantuan software Surfer 13 sehingga menghasilkan pola sebaran nilai tahanan jenis tanah pada setiap kedalaman. Variasi nilai tahanan jenis tanah pada kedalaman 0,5 m (tabel 3) memperlihatkan bahwa nilai tahanan jenis tanah tertinggi yaitu pada sampel S.01A sebesar $24,500 \Omega \mathrm{m}$ dan terendah yaitu pada sampel S.02A sebesar $14,210 \Omega \mathrm{m}$. Dengan mengacu pada tabel 2 diatas, korosifitas tanah pada kedalaman 0,5 $\mathrm{m}$ berada pada zona korosifitas sedang-tinggi (gambar 8). Zona korosifitas tinggi tersebar mulai dari tengah hingga timur laut daerah penelitiian.

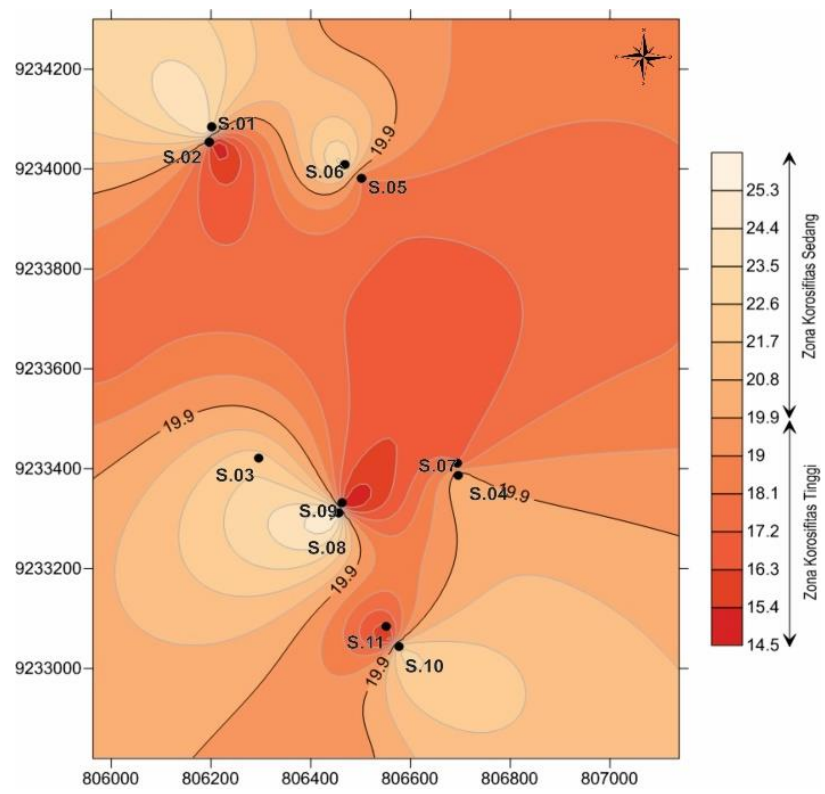

Gambar 8. Pola Sebaran Nilai Tahanan Jenis Tanah Pada Kedalaman $0.5 \mathrm{~m}$ 
Tabel 3. Klasifikasi Korosifitas Tanah Pada Kedalaman Sampel 0.5m

\begin{tabular}{c|cc}
\hline Sampel & $\begin{array}{c}\text { Nilai Tahanan } \\
\text { Jenis }(\Omega m)\end{array}$ & $\begin{array}{c}\text { Tingkatan } \\
\text { Korosifitas }\end{array}$ \\
\hline S.01A & 24,500 & Sedang \\
S.02A & 14,210 & Tinggi \\
S.03A & 22,320 & Tinggi \\
S.04A & 20,835 & Sedang \\
S.05A & 18,000 & Tinggi \\
S.06A & 23,990 & Sedang \\
\hline
\end{tabular}

tahanan

jenis tanah tertinggi yaitu pada sampel S.04B sebesar $20.110 \Omega m$ dan terendah yaitu pada sampel S.09B sebesar $10,210 \Omega \mathrm{m}$. Dengan mengacu pada tabel 2 diatas, korosifitas tanah pada kedalaman 1,0 $\mathrm{m}$ berada pada zona korosifitas sedang-tinggi (gambar 9). Zona korosifitas tinggi tersebar mulai dari tenggara hingga ke tengah daerah penelitiian.

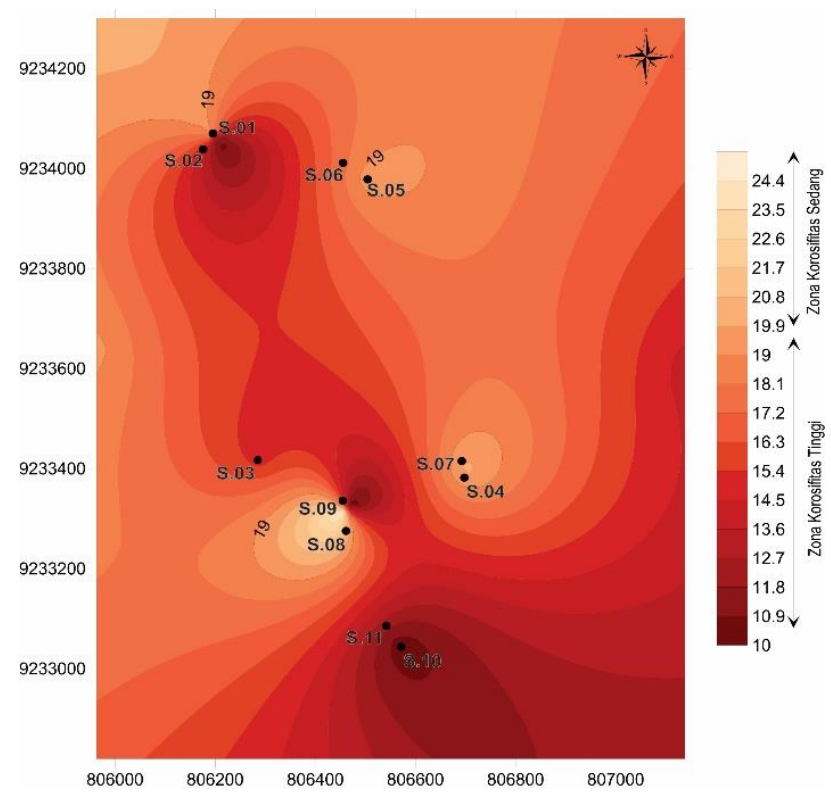

Gambar 9. Pola Sebaran Nilai Tahanan Jenis Tanah Pada Kedalaman 1.0m

Tabel 4. Klasifikasi Korosifitas Tanah Pada Kedalaman Sampel 1.0m

\begin{tabular}{c|cc}
\hline Sampel & $\begin{array}{c}\text { Nilai Tahanan } \\
\text { Jenis }(\Omega \mathrm{m})\end{array}$ & $\begin{array}{c}\text { Tingkatan } \\
\text { Korosifitas }\end{array}$ \\
\hline S.01B & 19,120 & Tinggi \\
S.02B & 10,320 & Tinggi \\
S.03B & 17,320 & Tinggi \\
S.04B & 20,110 & Sedang \\
\hline
\end{tabular}

\begin{tabular}{l|cc}
\hline S.07A & 17,145 & Tinggi \\
S.08A & 25,815 & Sedang \\
S.09A & 14,300 & Tinggi \\
S.10A & 23,095 & Sedang \\
S.11A & 15,000 & Tinggi \\
\hline
\end{tabular}

Variasi nilai tahanan jenis tanah pada kedalaman 1,0 m (tabel 4) memperlihatkan bahwa nilai

\begin{tabular}{c|cc}
\hline S.05B & 19,430 & Tinggi \\
S.06B & 18,240 & Tinggi \\
S.07B & 16,210 & Tinggi \\
S.08B & 18,220 & Sedang \\
S.09B & 10,210 & Sedang \\
S.10B & 10,340 & Tinggi \\
S.11B & 10,625 & Tinggi \\
\hline
\end{tabular}

Variasi nilai tahanan jenis tanah pada kedalaman 1,5 m (tabel 5) memperlihatkan bahwa nilai tahanan jenis tanah tertinggi yaitu pada sampel $\mathrm{S} .05 \mathrm{C}$ sebesar $17,330 \Omega \mathrm{m}$ dan terendah yaitu pada sampel S.07C sebesar $10,00 \Omega \mathrm{m}$. Dengan mengacu pada tabel 2 diatas, korosifitas tanah pada kedalaman 1,5 m berada pada zona korosifitas sedang-tinggi (gambar 10). Zona korosifitas tinggi tersebar di semua wilayah daerah penelitian.

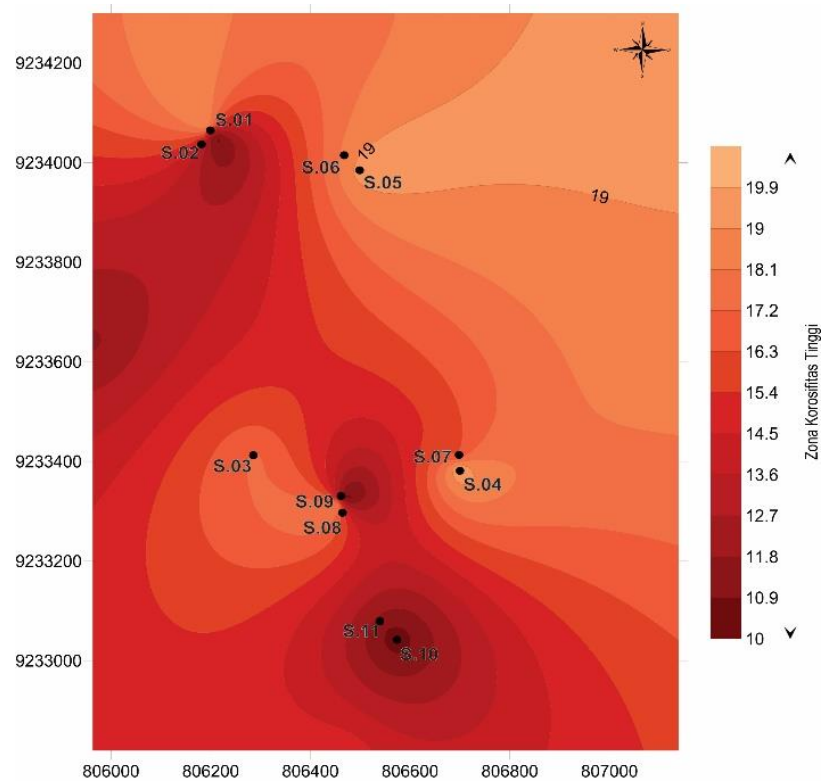

Gambar 10. Pola Sebaran Nilai Tahanan Jenis Tanah Pada Kedalaman 1.5m 
Tabel 5. Klasifikasi Korosifitas Tanah Pada Kedalaman Sampel 1.5m

\begin{tabular}{c|cc}
\hline Sampel & $\begin{array}{c}\text { Nilai Tahanan } \\
\text { Jenis }(\Omega \mathrm{m})\end{array}$ & $\begin{array}{c}\text { Tingkatan } \\
\text { Korosifitas }\end{array}$ \\
\hline S.01B & 15,430 & Tinggi \\
S.02B & 12,000 & Tinggi \\
S.03B & 16,770 & Tinggi \\
S.04B & 12,020 & Tinggi \\
S.05B & 17,330 & Tinggi \\
S.06B & 14,450 & Tinggi \\
S.07B & 10,000 & Tinggi \\
S.08B & 15,000 & Tinggi \\
S.09B & 12,000 & Tinggi \\
S.10B & 12,000 & Tinggi \\
S.11B & 14,000 & Tinggi \\
\hline
\end{tabular}

Tanah dengan ukuran butir halus (Clay-Silt) memiliki kemampuan menyerap volume air dengan jumlah yang lebih besar dibanding dengan jenis tanah lainnya. Hal ini terlihat pada grafik dibawah yang menunjukkan bahwa, semakin tinggi nilai persentase butiran halus maka semakin tinggi kadar air. Hubungan korelasi ( $r$ ) antara kedua variable tersebut sebesar 0,6067 dan termasuk kedalam korelasi kuat (Sugiyono, 2008).

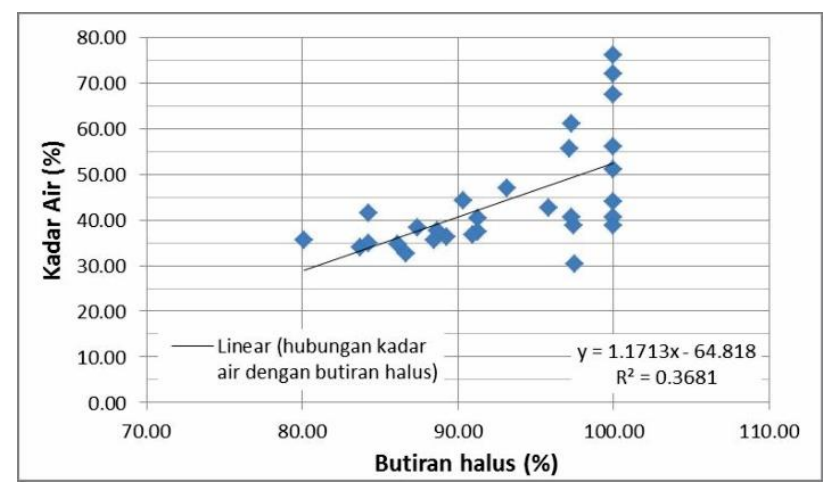

Gambar 11. Grafik Hubungan Persentase Butiran Halus Dengan Persentase Kadar Air

Air berperan sebagai elektrolit ketika terjadi peristiwa korosi secara elekto-kimia pada tanah. Peristiwa ini terjadi ketika adanya interaksi antara logam dan tanah. Parameter penting yang berperan secara signifikan dalam menentukan laju korosifitas adalah tahanan jenis tanah (Okiongbo dan Ogobiri, 2013).

Semakin rendah nilai tahanan jenis tanah maka tanah semakin korosif (tabel 2). Parameterparameter yang berpengaruh terhadap nilai tahanan jenis tersebut adalah air dan persentase besar butir pada tanah.

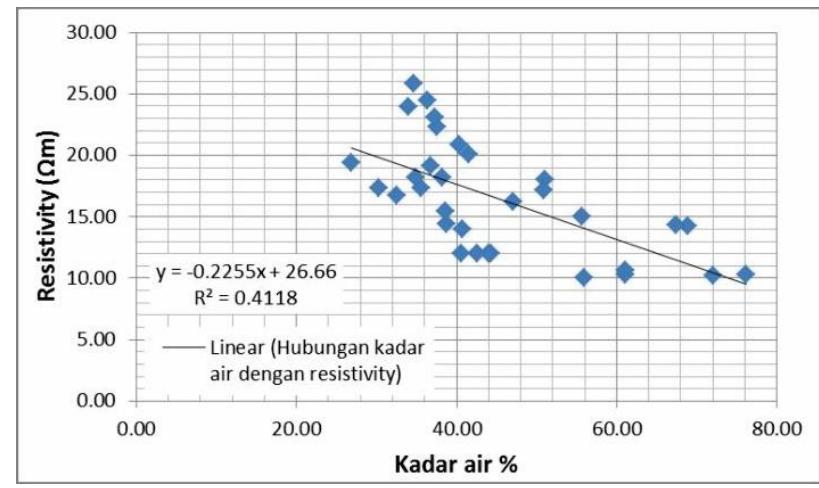

Gambar 12. Grafik Hubungan Nilai Tahanan Jenis Tanah Dengan Persentase Kadar Air

Grafik diatas menunjukkan bahwa semakin tinggi kadar air maka semakin rendah nilai tahanan jenis tanah. Hubungan korelasi $(r)$ antara kedua variable tersebut sebesar 0,6417 dan termasuk kedalam korelasi kuat (Sugiyono, 2008).

Berdasarkan hasi analisis besar butir/uji ayak terlihat bahwa persentase tanah berbutir halus (claysilt) lebih dominan dibanding dengan persentase butiran kasar (sand-gravel). Selanjutnya nilai persentase besar butir dan tahanan jenis tanah diplotting kedalam grafik untuk mengetahui sejauh mana hubungan pada kedua parameter tersebut.

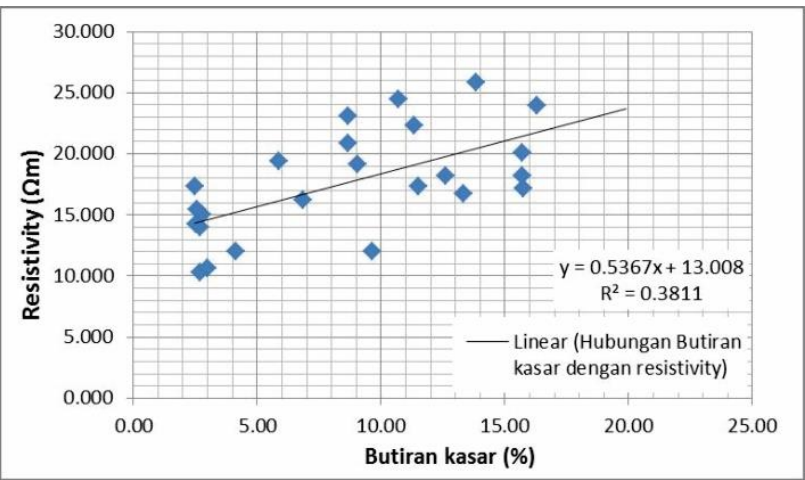

Gambar 13. Grafik Hubungan Nilai Tahanan Jenis Tanah Dengan Persentase Butiran Kasar (SandGravel) 
Grafik diatas menunjukkan bahwa semakin tinggi persentase butiran kasar maka semakin tinggi nilai tahanan jenis. Hubungan korelasi $(r)$ antara kedua variable tersebut sebesar 0,6173 dan termasuk kedalam korelasi kuat (Sugiyono, 2008).

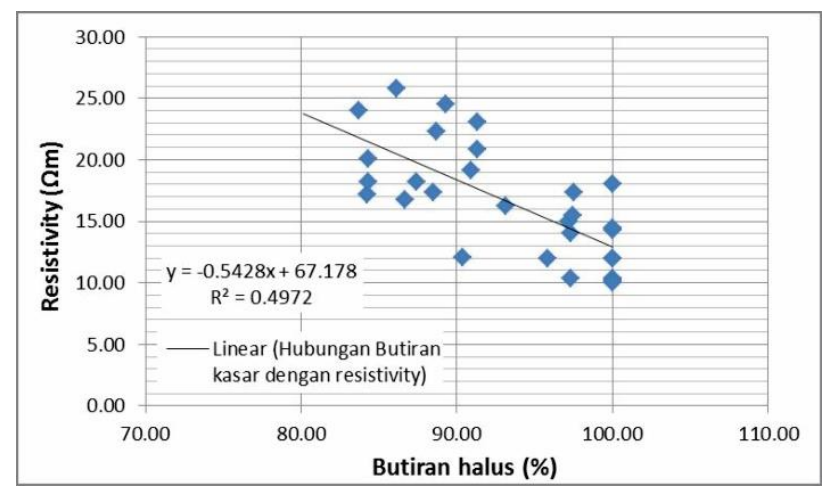

Gambar 14. Grafik Hubungan Nilai Tahanan Jenis

Tanah Dengan Persentase Butiran Halus (Clay-Silt)

Pada gambar 14 terlihat bahwa semakin tinggi persentase butiran halus maka semakin rendah nilai tahanan jenis. Hubungan korelasi $(r)$ antara kedua variable tersebut sebesar 0,7051 dan termasuk kedalam korelasi kuat (Sugiyono, 2008).

\section{PEMBAHASAN}

Tanah di daerah penelitian didominasi oleh tanah berbutir halus sebagai hasil dari proses pelapukan batuan vulkanik kuarter yang mengandung banyak mineral silika. Tanah dengan ukuran butir halus (Clay-Silt) memiliki kemampuan menyerap volume air dengan jumlah yang lebih besar. Hubungan antara kadar air dan persentase butiran halus menunjukkan korelasi positif dan kuat (gambar 11) artinya semakin tinggi persentase nilai butiran halus pada tanah maka semakin tinggi kadar airnya (Farahnaz dkk., 2018).

Hal ini diakibatkan karena salah satu sifat umum dari mineral lempung yang terdapat pada tanah dengan butiran halus adalah kemampuan hidrasi yaitu dikelilinginya pertikel lempung oleh partikel air/menyerap air sehingga menyebabkan kadar air pada tanah cenderung tinggi (Afif, 2016). Semakin tinggi kadar air dalam tanah maka nilai tahanan jenisnya akan semakin rendah (Irianto dan Rahmawati, 2014).

Hubungan korelasi antara nilai tahanan jenis tanah dan persentase kadar air ini bernilai kuat terlihat pada (gambar 12). Parameter kuat lain yang berpengaruh terhadap nilai tahanan jenis tanah adalah besar butir. Tanah dengan derajat pelapukan tinggi memiliki besar butir yang relatif lebih halus. Semakin tinggi persentase butiran kasar, semakin tinggi nilai tahanan jenis tanahnya (gambar 7). Perbedaan derajat pelapukan suatu batuan sampai menjadi tanah menjadi salah satu sebab terdapatnya perbedaan nilai tahanan jenis tanah (Reynolds, 2011).

Hubungan nilai tahanan jenis tanah dan persentase butiran halus maupun kasar menunjukkan korelasi kuat (gambar 13 dan gambar 14). Semakin tinggi persentase butiran kasar pada tanah maka semakin tinggi nilai tahanan jenisnya. Sebaliknya, semakin tinggi persentase butiran halus pada tanah maka semakin rendah nilai tahanan jenisnya.

Potensi korosifitas tanah di daerah penelitian berdasarkan klasifikasi korosifitas tanah (tabel 2) berada pada tingkatan sedang-tinggi. Hal ini diakibatkan karena nilai tahanan jenis tanah yang beragam. Nilai tahanan jenis tanah mempunyai peranan penting dalam menentukan laju korosifitas (Okiongbo dan Ogobiri, 2013). Artinya nilai tahanan jenis tanah yang rendah (konduktivitas tinggi) menghasilkan tingkat korosifitas yang tinggi. Sebaliknya, nilai tahanan jenis tanah yang tinggi (konduktivitas rendah) menghasilkan tingkat korosifitas yang rendah.

Variabel lain yang harus diperhitungkan untuk klasifikasi korosifitas tanah selain nilai tahanan jenis adalah derajat keasaman tanah $(\mathrm{pH})$. Nilai derajat keasaman $(\mathrm{pH})$ disebabkan oleh Flokulasi dan Dispersi yang terjadi pada tanah. Semakin asam tanah semakin tinggi tingkat korosifitasnya.

Angka pH tanah di daerah penelitian berkisar antara 6,19-6,49 (Arifin, 2018) dengan kata lain sifat korosifitas tanahnya netral. Pada rentang nilai tersebut, $\mathrm{pH}$ bukanlah variabel dominan yang mempengaruhi laju korosifitas tanah. 


\section{PENUTUP}

\section{Simpulan dan Saran}

Tanah di daerah penelitian merupakan tanah berbutir halus dan masuk kedalam klasifikasi berjenis Lanau dengan tingkat Plastisitas Rendah-Tinggi (MH$\mathrm{ML}$ ) serta Lempung dengan tingkat Plastisitas Tinggi (CH).

Hasil analisis dari sebaran potensi korosifitas tanah di daerah penelitian menunjukkan bahwa tingkat korosifitas tanah berada pada tingkatan sedang-tinggi. Zona korosifitas tinggi pada sampel dengan kedalaman 0,5 $\mathrm{m}$ terkonsentrasi di sebelah barat laut, pada sampel dengan kedalaman 1,0 m terkonsentrasi disebelah tenggara, dan pada sampel dengan kedalaman 1,5m tersebar diseluruh daerah penelitian. Parameter yang berperan secara signifikan terhadap korosifitas adalah nilai tahanan jenis tanah. Beberapa variable kuat yang berpengaruh terhadap nilai tahanan jenis tanah yaitu: kadar air dan besar butir tanah.

Pengambilan sampel tanah dilakukan pada bulan oktober-november ketika musim peralihan dari kemarau ke penghujan. Untuk mengetahui potensi korosifitas tanah ketika keadaan maksimum (kondisi terburuk). Disarankan pengambilan sampel dilakukan ketika tanah diperkirakan sedang jenuh air atau ketika musim penghujan.

\section{Ucapan Terima Kasih}

Penulis mengucapkan terimakasih kepada Zufialdi Zakaria dan Dicky Muslim selaku pembimbing yang telah meluangkan banyak waktu, kesabaran, juga memberikan arahan dalam menyelesaikan karya tulis ini. Serta kepada keluarga dan teman-teman semua yang selalu menyemangati hingga akhir studi.

\section{DAFTAR PUSTAKA}

Afif, N.N.H. (2016), Hubungan Mineral Lempung dengan Koefisien Konsolidasi Tanah di Kawasan Kecamatan Jatinangor, Kabupaten Sumedang, provinsi Jawa Barat Universitas Padjadjaran,.

Anon (2012), "Soil Corrosion". mechanicalbrothers. Diambil dari https://mechanicalbrothers.wordpress.com/20 12/07/04/soil-corrosion/.
Arifin, M., Putri, N.D., Sandrawati, A. dan Harryanto, R. (2018), "Pengaruh Posisi Lereng terhadap Sifat Fisika dan Kimia Tanah pada Inceptisols di Jatinangor", soilrens, Vol.16, No.2. http://doi.org/10.24198/soilrens.v16i2.20858.

ASTM G187-12 (2012), Test Method for Measurement of Soil Resistivity Using the Two-Electrode Soil Box Method, ASTM International. Diambil dari http://www.astm.org/cgibin/resolver.cgi?G187-12.

Bahri, S. (2007), "Penghambatan Korosi Baja Beton dalam Larutan Garam dan Asam dengan Menggunakan Campuran Senyawa Butilamina dan Oktilamina", Jurnal Gradien, Vol.3, No.1, hal. 231-236.

Bradford, S.A. (2001), Practical Handbook of Corrosion Control in Soils. Diambil dari https://www.abebooks.com/signed/PracticalHandbook-Corrosion-Control-SoilsPipelines/18244604681/bd.

Farahnaz, N., Sophian, R.I., Mulyo, A. dan Hendarmawan (2018), "POTENSI TANAH MENGEMBANG HASIL LAPUKAN BATUAN VULKANIK BERDASARKAN INDEKS PLASTISITAS DI KAWASAN DESA CILAYUNG", Geoscience Journal, Vol.2, No.1, hal. 82-89.

G Camitz (1994), Corrosion and Protection of Steel Piles and Sheet Piles in Soil and Water, Royal Swedish Academy of Engineering Sciences-Commission of Pile Research, hal. 133.

Hanafiah, K.A. (2007), "Dasar-dasar ilmu tanah / Kemas Ali Hanafiah", 1. TANAH, ILMU,Dasar-dasar ilmu tanah / Kemas Ali Hanafiah, Vol.2007, No.2007, hal. 1-99. http://doi.org/2007.

Hutabarat, J., Sendjaja, Y.A., Haryanto, A.D. dan IImi, N.N. (2016), Aplikasi Unsur Tanah Jarang (UTJ) Dalam Ilmu Geologi: Studi Kasus Petrogenetik Gunung Api Kwarter di Jawa Barat, hal. 6.

Irianto, A.I. dan Rahmawati, E. (2014), "Prototipe Alat Ukur Resistivitas Tanah Dengan Metode FourPoint Probes", Prosiding Pertemuan Ilmiah XXVIII HFI, Diambil dari https://www.academia.edu/27634921/Prototip e_Alat_Ukur_Resistivitas_Tanah_dengan_Meto de_Four_Point_Probes.

Lestari, D.S. (2019), "Perhitungan Nilai Korosivitas Air Terhadap Infrastruktur Sumber Daya Air Berbahan Logam", Jurnal Infrastruktur, Vol.5, hal. 72.

Muslim, D., Haerani, E., Sophian, I., Zakaria, Z., Khoirullah, N., Putra, Y.P. dan Shibayama, M. (2015), Engineering Geologic Mapping Around The Newly Built Higher Education Complex In Jatinangor, West Java, Indonesia, hal. 5.

N. Khoirullah (2016), Hubungan Ukuran Butir Tanah, Mmineral Lempung, dan Kemiringan Lereng Dengan Nilai Erodibilitas pada Tanah Lapukan 
Batuan Vulkanik Muda Jatinangor, Universitas Padjadjaran.

Okiongbo, K.S. dan Ogobiri, G. (2013), "Predicting Soil Corrosivity along a Pipeline Route in the Niger Delta Basin Using Geoelectrical Method: Implications for Corrosion Control", Engineering, Vol.5, No.3, hal. 237-244. http://doi.org/10.4236/eng.2013.53034.

Pritchard, O.G. dan Hallett, D.S.H. (2013), Soil Corrosivity in the UK - Impacts on Critical Infrastructure, hal. 55.

Putra, M.H.R. (2018), Analisis Sifat Fisi Batuan Karbonat Untuk Evaluasi Bahan Timbunan Institut Teknologi Sepuluh Nopember,.

Reiger, P.H. (1992), Electrochemistry - Second Edition. Diambil dari https://vdocuments.site/electrochemistrysecond-edition.html.

Reynolds, J.M. (2011), An Introduction to Applied and Environmental Geophysics, 2nd Edition. Diambil dari https://www.wiley.com/enus/An+Introduction+to+Applied+and+Environm ental+Geophysics\%2C+2nd+Edition-p9780471485353.

Sidiq, M.F. (2013), "ANALISA KOROSI DAN PENGENDALIANNYA", jurnal Foundry, Vol.3, No.1. Diambil dari https://www.academia.edu/12097573/ANALIS A_KOROSI_DAN_PENGENDALIANNYA.

Silitonga, P.H. (2003), Peta geologi lembar Bandung, Jawa. Diambil 31 Agustus 2020, dari https://opac.perpusnas.go.id/DetailOpac.aspx?i $d=719712$.

Sugiyono (2008), Metode penelitian pendidikan:(pendekatan kuantitatif, kualitatif dan R \& D), Alfabeta.

Thomas, G.W. dan Hargrove, W.L. (1984), The chemistry of soil acidity. In Adams, F (Ed). Soil Acidity and Liming Second edition, American Society of Agronomy Inc, USA.

U. S. Army Corps of Engineers (1997), Geophysical Exploration for Engineering and Environmental Investigations, Diambil dari https://cedb.asce.org/CEDBsearch/record.jsp?d ockey $=0109918$.

Wahyuni, T. dan Ab, S. (2014), "PEMANFAATAN TANIN EKSTRAK DAUN JAMBU BIJI TERHADAP LAJU KOROSI BESI DALAM LARUTAN $\mathrm{NaCl} 3 \%(\mathrm{w} / \mathrm{v}) "$, JURNAL KONVERSI, Vol.3, No.1. http://doi.org/10.24853/konversi.3.1.\%p.

Warnana, D.D., Iswahyudi, A. dan Prabawa, S.E. (2015), "Penentuan Area Korosi Tanah Lokal Berdasarkan Resistivitas Tanah untuk Perancangan Sistem Proteksi Katodik", Jurnal Geosaintek, Vol.1, No.1, hal. 43-46-46. http://doi.org/10.12962/j25023659.v1i1.1198. 